\title{
NEW REFINEMENTS OF GENERALIZED ACZÉL'S INEQUALITY AND THEIR APPLICATIONS
}

\author{
JingFEng Tian AND SHANHE Wu
}

Abstract. In this paper, we give several new refinements of generalized Aczél's inequality. Moreover, as applications, some new refinements of integral form of generalized Aczél-type inequality are given.

Mathematics subject classification (2010): Primary 26D15; Secondary 26D10.

Keywords and phrases: Aczél's inequality, Aczél-Popoviciu's inequality, Aczél-Vasić-Pečarić's inequality, Aczél-type inequality, refinement.

\section{REFERENCES}

[1] J. ACZÉL, Some general methods in the theory of functional equations in one variable. New applications of functional equations, Uspehi. Mat. Nauk (N. S.) 11, 3 (1956), 3-68 (in Russian).

[2] D. S. Mitrinović, J. E. PeČARIĆ AND A. M. Fink, Classical and New Inequalities in Analysis, Kluwer Academic, Dordrecht, 1993.

[3] T. Popoviciu, On an inequality, Gaz. Mat. Fiz. Ser. A 11, 64 (1959), 451-461 (in Romanian).

[4] J.-F. TIAN, Reversed version of a generalized Aczél's inequality and its application, J. Inequal. Appl. 2012 (2012), 202.

[5] P. M. VAsić And J. E. Pečarić, On Hölder and some related inequalities, Mathematica Rev. D’Anal. Num. Th. L'Approx. 25 (1982), 95-103.

[6] P. M. VAsić And J. E. PeČAriĆ, On the Jensen inequality for monotone functions, An. Univ. Timişoara Ser. Şt. Matematice 17, 1 (1979), 95-104.

[7] S. Wu, Some improvements of Aczél's inequality and Popoviciu's inequality, Comput. Math. Appl. 56, 5 (2008), 1196-1205.

[8] S. Wu And L. Debnath, Generalizations of Aczél's inequality and Popoviciu's inequality, Indian J. Pure Appl. Math. 36, 2 (2005), 49-62. 